\title{
Relative Effectiveness of Fiscal and Monetary Policies in Nigeria
}

\author{
David Iheke Okorie ${ }^{1}$, Manu Adasi Sylvester ${ }^{1} \&$ Dak-Adzaklo Cephas Simon-Peter ${ }^{1}$ \\ ${ }^{1}$ Wang Yanan Institute for Studies in Economics, Xiamen University, Xiamen, China \\ Correspondence: David Iheke Okorie, Wang Yanan Institute for Studies in Economics, Xiamen University, \\ Xiamen, Fujian, China.
}

Received: February 19, 2017

Accepted: March 9, 2017

Online Published: March 20, 2017

doi:10.20849/ajsss.v2i1.129

URL: https://doi.org/10.20849/ajsss.v2i1.129

\begin{abstract}
This study employs the auto regressive distributed lag (ARDL) model to ascertain the relative effectiveness of monetary and fiscal policies in Nigeria using a quarterly time-series from 1981-2012. From our analysis, it discovered that monetary and fiscal policies both have significant positive impact income. This conforms to a priori expectation and we discovered that monetary policy effects income faster than fiscal policy. In the short run, monetary policy effects income more than fiscal policy but the reverse is the case for the long run. Total impact of fiscal policy is higher than that of monetary policy. This study supports the use of both policies to achieve change in income but this depends on the objective the authorities want to achieve.
\end{abstract}

Keywords: monetary policy, fiscal policy, income

JEL Classification: E52, E62, E63, P24

\section{Introduction}

Sustainable economic growth and development is of no doubt, one of the most challenging development issues in the Third World countries today. It is also true that the focus of macroeconomic thinkers and policy makers is how to attain macroeconomic stability. The two major economic policies often used to stabilize any economy of the world are monetary and fiscal policies and their cardinal tools are money supply and government expenditure, respectively (Asogu, 1998). On the one hand, monetary policy defined as the actions of a central bank that determine the size and rate of growth of the money supply, which in turn affects interest rates. Monetary policy maintained through actions such as changing the interest rate, or the amount of money banks need to keep in the vault. On the other hand, fiscal policy has to do with changing government expenditure and tax to achieve a given macroeconomic objective. Today, fiscal and monetary policies are linked heavily in macroeconomic management as they augment each other. There is a consensus among economists that both policies individually and collectively affect the income of a nation but the degree of relative effectiveness of these policies has been the source of controversies and debates among economists. It is based on this controversies and debates that this study re-examines the relative effectiveness of fiscal and monetary policies on national income in Nigeria with the use of quarterly time series from 1981-2012. The autoregressive distributed lag (ARDL) model technique is employed to analyze the data and draw policy inferences.

\subsection{Theoretical Literature Review}

\section{- Wagner's Law of Increasing State Activities}

Adolph Wagner, a German Economist, in 1883 formulated the law of increasing state activity commonly referred to as Wagner's law. This theory emphasizes that economic growth is the fundamental determinant of public sector growth. Wagner's law states that as per capita income in a country rises, the relative size of the public sector also increases. The increase in per capita income is associated with an increase in the demand for public services such as transport and communication networks, waste disposal, etc. As a result of this demand for public services, new functions are continuously being undertaken and old ones are being performed efficiently and on a larger scale that increases the spending of the government. Thus, social progress brings about an increase in state activity which in turn means more government expenditure (Henrekson, 1993 in Verma and Arora, 2010). The three functions of the state that Wagner recognized are: Providing administration and protection; ensuring stability; and providing for the economic and social welfare of the society as a whole.

\section{- Peacock and Wiseman Displacement Effect}

Peacock and Wiseman (1967) are of the view that government expenditure depends broadly on revenue raised by taxation and that government expenditure is dependent on taxation. They theorized the "displacement effect", 
where they explained that social upheavals or disturbances such as famine or national crises would lead to an increase in public expenditure, since the government may convince tax payers that higher taxes are necessary to prevent a national disaster. They maintained that after the crisis had subsided, government expenditure could even remain at the new post-crisis level because tax payers would become accustomed to the higher levels of taxation and accept them as part of life (Black et al, 1999).

\section{- Fisher's Model}

Fisher's model gives the equation of exchange. The relationship is given by the equation $M V=P Y$

$V$ is the income velocity of circulation of money, $M$ is nominal money supply, $P$ is the price level, $Y$ is the total output produced and $P Y$ gives the total income in the economy. The equation of exchange shows that aggregate income is dependent on nominal money supply and the relationship between them is positive. This implies that increase in nominal money supply leads to increase in the aggregate income of the economy.

\subsection{Empirical Literature Review}

Adefeso and Mobolaji (2010) re-estimated and re-examined the relative effectiveness of monetary and fiscal policies on economic growth in Nigeria using an annual time series data from 1970-2007. They employed Error Correction Mechanism and Cointegration techniques. Their empirical results showed that a monetary policy has a stronger effect than fiscal policy and the exclusion of the degree of openness did not weaken this conclusion. They suggested more that more emphasis and reliance be laid on monetary policy for economic stabilization in Nigeria.

Isaka, Abdulraheem, and Mustapha (2011) used a time series data from 1995-2004 tried to determine the impact of fiscal and monetary policies on the level of economic activities in Nigeria. Their study showed that recurrent and capital expenditure, taxes and money supply do not significantly explain variations in the level of economic activities in Nigeria. They explained that it could be as a result of improper use of tax revenue to stimulate economic growth.

Oziengbe (2011) examined the relative effectiveness of monetary and fiscal policy in Nigeria using a quarterly time series data from 1981-2009. He employed cointegration and error correction methodology. His results showed a significant positive relationship between real gross domestic product and government expenditure and a positive relationship between real gross domestic product and one-quarter lagged value of money supply. He further discovered that the impact of monetary policy action was delayed till the next quarter while fiscal policy action in current quarter was observed to impact positively on economic activities in the current quarter. The result also showed that the positive impact of monetary policy action on economic activities was more significant than that of fiscal policy within the period covered by the study. He concluded that both policies should be seen as complementary demand management policies and each should be implemented in economic situations for which they are best suited.

Sanni, Amusa, and Agbeyangi (2012) using an annual time series data from 1960-2011, investigated the superiority of fiscal and monetary policies in controlling economic activities in Nigeria. Error Correction methodology was employed and the empirical result showed that none of the policies can be said to be superior to another and that a proper mix of the policies may enhance a better economic growth.

Iyeli, Uda, and Akpan (2012) focused on the relative effectiveness of Broad Money Supply and Government Fiscal Deficits with respect to their influences on economic activity represented by the Gross Domestic Product (GDP) in a bid to investigate the relative effectiveness of monetary and fiscal policy. A yearly time series data from 1970-2001 was used and a cointegration and error-correction modeling was applied to establish the extent of the quantitative impact and relative significance of the variables. They discovered that contribution of Broad Money Supply $\left(\mathrm{MS}_{2}\right)$ to the inflationary cycle in Nigeria is weak, but its immediate year lagged value is strong, positive and significant. The effects of Money Supply factors on inflation in Nigeria appeared dominant, while the role of Fiscal Deficit is pervasive. Also the study confirmed that the role of fiscal policy (especially Fiscal Deficits) although positive, is negligible and in some instances not significant in influencing cyclical inflation rate in Nigeria within the period under review. Their output model showed that the effect of monetary policy on output growth has an edge over fiscal policy variable as a measure of output stabilization. The fiscal policy factor, although statistically insignificant, also has a negative association with the domestic output factor. They concluded that fiscal policy efforts of the Federal Government of Nigeria are not positive in stimulating output growth.

Nathan Pelesai (2012) using a time series data from 1970-2010 carried out a causal analysis, a cointegration error correction model, a two band recursive least square to test for the stability of the Nigerian economy as well as find out the effect of money supply, fiscal deficits and exports on the relative effectiveness of fiscal policies in the Nigeria. He discovered the existence of a significant causal relationship between gross domestic product and the variables mentioned earlier. 
Yakubu, Barfour, and Shehu (2013) using impulse response and variance decomposition analyses and an annual time series data from 1963-2012 investigated the effectiveness of monetary-fiscal policies interaction on price and output growth in Nigeria. They discovered that the policy variables money supply and government revenue have more positive impact on price and economic growth in Nigeria particularly in the long run, thus some time with lag. Their results further showed that economic activity is dominated by its own dynamics in most of the periods. The estimates presented in their study suggested that both monetary and fiscal policy exert greater impact on real GDP and inflation in Nigeria.

Existing works have made tremendous effort in examining and estimating the causal impact of monetary and fiscal policies in an economy and failed to account for the differences in the economic impact framework (Long run and Short run impacts). This work therefore, made efforts in determining the relative effectiveness of these policies in different frameworks (long run and short run) so as to be able to choose and make appropriate cum robust policies to achieve different long run and short run set goals.

\section{Research Methodology}

The methodology used in this research work is the autoregressive distributed lag (ARDL) model. The level form model to be employed in this study is given as

$$
L n G D P_{t}=\delta L n M S S_{t}+\theta \operatorname{LnTGE} E_{t}+U_{t}
$$

Where

$G D P=$ Logarithm of Gross Domestic Product by Income (Proxy for national income)

LnMSS = Logarithm of Money Supply (Proxy for monetary policy)

$\operatorname{LnTGE}=$ Logarithm of Total Government Expenditure (Proxy for fiscal policy)

The restricted error correction model is given as

$$
\Delta L n N G D P=\alpha+\sum_{i=1}^{k} \beta_{i} \Delta L n G D P_{t-i}+\sum_{i=0}^{n} \delta_{i} \Delta L n M S S_{t-i}+\sum_{i=0}^{n} \theta_{i} \Delta L n T G E_{t-i}+\vartheta U_{t-1}+V_{t}
$$

The unrestricted error correction model is given as

$$
\begin{aligned}
\Delta L n N G D P & =\alpha+\sum_{i=1}^{k} \beta_{i} \Delta L n G D P_{t-i}+\sum_{i=0}^{n} \delta_{i} \Delta \operatorname{LnMSS}_{t-i}+\sum_{i=0}^{n} \theta_{i} \Delta L n T G E_{t-i}+\rho G D P_{t-1}+\varphi L n M S S_{t-1} \\
& +\omega L n T G E_{t-1}+V_{t}
\end{aligned}
$$

A MacKinnon, White, and Davidson (MWD) test for functional form of regression was carried out and the test validated the use of a log-linear model. The model will be validated based on the road map of autoregressive models. The variables will be subjected to unit root test to ensure that they are all integrated of an order not greater than two. In other words, the variables will be tested to see if they are integrated of order zero or one. The lag structure of the unrestricted error correction model will be determined. A serial correlation test will be carried out to ensure that the error terms are serially independent. A stability test will be carried out to ensure that the autoregressive part of the model is dynamically stable. A bound test will also be carried out to know if there is existence of long run relationship among the variables.

\subsection{Data Analysis and Interpretation}

\section{- Unit Root Test}

Table 1. Result for Augmented Dickey Fuller Unit Root Test

\begin{tabular}{ccccc}
\hline Variable & $A D F_{C a l}$ & $A D F_{T a b}$ & P-Value & Order of integration \\
\hline $\boldsymbol{L n} \boldsymbol{G D P}$ & -4.031052 & -3.446765 & 0.0101 & $\mathrm{I}(1)$ \\
\hline $\boldsymbol{L n} \boldsymbol{M S S}$ & -3.701245 & -3.568379 & 0.0378 & $\mathrm{I}(1)$ \\
\hline $\boldsymbol{L n T \boldsymbol { G }} \boldsymbol{}$ & -4.353657 & -3.574244 & 0.0090 & $\mathrm{I}(1)$ \\
\hline
\end{tabular}

Source: Researchers' Computation using Eviews7.2 
From the table above, all the variables of interest have unit root. These variables were differenced and they were all integrated of order one.

\section{- Lag Order Selection Criteria}

Table 2. The Lag Length Structure of the Model

\begin{tabular}{cc}
\hline Variable & Lags to be Included in the Model \\
\hline $\boldsymbol{G D P}$ & 8 \\
\hline $\boldsymbol{L n} \boldsymbol{M S S}$ & 4 \\
\hline $\boldsymbol{L n T \boldsymbol { E }}$ & 4 \\
\hline
\end{tabular}

Source: Researchers' Computation using Eviews7.2

Using Akaike information criterion (AIC) and Schwarz information criterion (SIC) selection criterion, the lags given in the table above were selected.

Based on the selected lags, the restricted error correction model is given as

$$
\begin{aligned}
\Delta L n N G D P=\alpha & +\sum_{i=1}^{8} \beta_{i} \Delta L n G D P_{t-i}+\sum_{i=0}^{4} \delta_{i} \Delta L n M S S_{t-i}+\sum_{i=0}^{4} \theta_{i} \Delta L n T G E_{t-i}+\vartheta U_{t-1} \\
& +V_{t}
\end{aligned}
$$

The unrestricted error correction model is given as

$$
\begin{aligned}
\Delta L n N G D P & =\alpha+\sum_{i=1}^{8} \beta_{i} \Delta L n G D P_{t-i}+\sum_{i=0}^{4} \delta_{i} \Delta L n M S S_{t-i}+\sum_{i=0}^{4} \theta_{i} \Delta L n T G E_{t-i}+\rho G D P_{t-1}+\varphi L n M S S_{t-1} \\
& +\omega L n T G E_{t-1}+V_{t}
\end{aligned}
$$

\section{- Serial Correlation Test}

Table 3. Serial Correlation Test Result

\begin{tabular}{ccc}
\hline Lags & P-Value & Conclusion \\
\hline $\mathbf{0}$ & 0.6231 & No serial correlation \\
\hline
\end{tabular}

Source: Researchers' Computation using Eviews7.2

From the details in the table above, it is seen that the errors in the unrestricted error correction model are serially independent.

- Dynamic Stability Test

The model is dynamically stable as all the inverse autoregressive (AR) roots fall within the circle. See appendix E1

\section{○ Bound Test}

Table 4. Bound Test Result for Long Run Relationship

\begin{tabular}{lcccll}
\hline Null Hypothesis & F-Stat & $\begin{array}{l}\text { Lower } \\
\text { Bound }\end{array}$ & $\begin{array}{l}\text { Upper } \\
\text { Bound }\end{array}$ & Decision & Conclusion \\
\hline $\begin{array}{l}\boldsymbol{C}(\mathbf{2 0})=\boldsymbol{C}(\mathbf{2 1}) \\
=\boldsymbol{C}(\mathbf{2 2})=\mathbf{0}\end{array}$ & 4.347412 & 3.17 & 4.14 & $\begin{array}{l}C(20) \neq C(21) \\
\neq C(22) \neq 0\end{array}$ & $\begin{array}{l}\text { There is long run equilibrium } \\
\text { relationship }\end{array}$ \\
\hline
\end{tabular}

Source: Researchers' Computation using Eviews7.2 
The details of the above table show that at $10 \%$ level of significance is a long run relationship among the variables of interest as the value of the F-statistics fall above the upper bound value.

\subsection{Restricted Error Correction Model}

Table 5. Restricted Error Correction Regression Result

\begin{tabular}{cccc}
\hline Dependent variable: GDP & & \\
\hline Variable & Coefficient & T-Statistic & P-Value \\
\hline $\boldsymbol{D}($ LnMSS $)$ & 0.381650 & 2.925266 & 0.0043 \\
\hline $\boldsymbol{D}($ LnTGE $)$ & 0.231681 & 2.734895 & 0.0074 \\
\hline$($ Residuals $(-\mathbf{1}))$ & -0.880588 & -3.297222 & 0.0014 \\
\hline
\end{tabular}

Source: Researchers' Computation using Eviews7.2

See appendix G1 for complete result. The short run impact is gotten from the restricted error correction model. The short run impact of money supply on income is given by 0.381650 while the short run impact of total government expenditure on income is given by 0.231681 . This implies that in the short run, holding other variables constant, the elasticity of income with respect to money supply is 0.38 . This suggests that a percentage increase in money supply, on average, leads to a 0.38 percent increase in income. Also, in the short run, holding other variables constant, the elasticity of income with respect to total government expenditure is 0.23 suggesting that a percentage increase in government expenditure, on average, leads to a 0.23 percent increase in income.

The coefficient of the lagged residual is statistically significant and it lies between -1 and 0 . This means that $88 \%$ of the disequilibrium in income is corrected within a quarter (that is three months). Also, the reciprocal of the lagged residual in absolute terms give the length of time it takes for disequilibrium to be completely adjusted. $(1 / 0.880588=3$ months and 12 days $)$ Implies that it will take 3months and 22days for equilibrium in output to be fully restored.

\subsection{Unrestricted Error Correction Model}

Table 6. Unrestricted Error Correction Regression Result

\begin{tabular}{cccc}
\hline Dependent variable: GDP & & & \\
\hline Variable & Coefficient & T-Statistic & P-Value \\
\hline $\boldsymbol{G D P}(-\mathbf{1})$ & -0.252710 & -3.546637 & 0.0006 \\
\hline $\boldsymbol{L n} \boldsymbol{M S S}(-\mathbf{1})$ & 0.102311 & 2.305657 & 0.0233 \\
\hline $\boldsymbol{L n T \boldsymbol { E }}(-\mathbf{1})$ & 0.163010 & 2.775903 & 0.0066 \\
\hline
\end{tabular}

Source: Researchers' Computation using Eviews7.2

See appendix $\mathrm{C} 1$ for complete result. The long run impact is extracted from the unrestricted error correction model.

Table 7. Long Run Impact of the Independent Variables on the Dependent Variables

\begin{tabular}{cc} 
Variable & Long Run Impact \\
\hline $\boldsymbol{M S S}$ & $-{ }^{\varphi} / \rho=-0.102311 /{ }_{(-0.252710)}=0.4048553678$ \\
\hline $\boldsymbol{T G E}$ & $-\omega / \rho=--0.16301 /{ }_{(-0.252710)}=0.6450476831$
\end{tabular}

Source: Researchers' Computation 
This implies that in the long run, holding other variables constant, a percentage increase in money supply, on average, leads to a 0.40 percent increase in income. Also, a percentage increase in government expenditure, on average, leads to a 0.65 percent increase in income.

\section{Conclusion and Recommendation}

From analysis, it was discovered that monetary policy has a faster speed compared to fiscal policy. In the short run, the impact of monetary policy on income is higher than the impact of fiscal policy on income. In the long run, the impact of fiscal policy on income is higher than the impact of monetary policy on income. In the short run, monetary policy has the highest impact in the short run. On the other hand, fiscal policy has the highest impact in the long run. When the impacts of these policies in both periods are summed, it is seen that fiscal policy has a greater impact on income than monetary policy has on income.

In conclusion, monetary policy has a faster impact on income than fiscal policy but fiscal policy has a greater impact on income. Based on speed monetary policy is relatively effective but based of magnitude, fiscal policy is more effective.

Finally, this research work supports the use of both policies but this depends on the objective the authorities want to achieve. If the government wants a policy that will increase/decrease income faster, then an expansionary/contractionary monetary policy should be employed. If on the other hand, if a policy that will have a greater impact on income is required, then fiscal policy should be employed.

\section{References}

Abata, M., Kehinde, J., \& Bolarinwa, S. (2012). Fiscal/Monetary Policy and Economic Growth in Nigeria: A Theoretical Exploration. International Journal of Academic Research in Economics and Management Sciences, 1(5).

Adefeso, H. A., \& Mobolaji, H. I. (2010). The Fiscal-Monetary Policy and Economic Growth in Nigeria: Further Empirical Evidence. Pakistan Journal of Social Sciences, 7(2), 137-142.

Black, P.A., Calitz, E., Steenekamp, T. J., \& Associates. (1999). Public Economics for South African Students. Southern Africa: Cape Town Oxford University Press.

Isaka, S., Abdulraheem, A., \& Mustapha, I. (2011). Impact of fiscal and monetary policies on the level of economic activities in Nigeria. LAPAI Journal of management science, 1(2).

Iyeli, I. I., Uda, E.B., \& Akpan, E. (2012). The Relative Effectiveness of Monetary and Fiscal Policies in Economic Stabilization in a Developing Economy: An Empirical Evidence from Nigeria. Annals of Humanities and Development Studies, 3(1).

Mankiw, G. N. (2001). Macroeconomics.

Nathan, P. A. (2012). The Impact of Fiscal Policy on the Nigerian Economy. International Review of Social Sciences and Humanities, 4(1), 142-150.

Oziengbe, S. A. (2011). Examining the Relative Effectiveness of Monetary and Fiscal Policies in Nigeria: A Cointegration and Error Correction Approach. Working Papers Series.

Randall, W. E., \& Timothy, J. G. (1992). Wagner's Hypothesis: A Local perspective. Working paper 9202, 1-34.

Sanni, M. R., Amusa, N. A., \& Agbeyangi, B. A. (2012). Potency of Monetary and Fiscal Policy Instruments on Economic Activities of Nigeria (1960-2011). Journal of African Macroeconomic Review, 3(1), 161-176.

Snowdon, B., \& Vane, H. (2005). Modern Macroeconomics, Its Origins, Development and Current State. Edward Elgar Publishing Limited, UK.

Verma, S., \& Arora, R. (2010). Does the Indian Economy Support Wagner's Law? An Econometric Analysis. Eurasian Journal of Business and Economics, 3(5), 77-91.

Yakubu, M., Barfour, K. A., \& Shehu U. G. (2013). Effect of Monetary-Fiscal Policies Interaction on Price and Output Growth in Nigeria. CBN Journal of Applied Statistics, 4(1), 55-73. 
Appendix A1. Dickey Fuller Unit Root Test Result

\section{Logarithm of Gross Domestic Product by Income(LnGDPI)}

Null Hypothesis: D(LNGDP) has a unit root

Exogenous: Constant, Linear Trend

Lag Length: 3 (Automatic - based on SIC, maxlag=12)

\begin{tabular}{lccc}
\hline \hline & t-Statistic & Prob. $^{*}$ \\
\hline \hline Augmented Dickey-Fuller test statistic & -4.031052 & 0.0101 \\
\hline Test critical values: & $1 \%$ level & -4.034356 & \\
& $5 \%$ level & -3.446765 & \\
& $10 \%$ level & -3.148399 & \\
\hline \hline
\end{tabular}

*MacKinnon (1996) one-sided p-values.

Augmented Dickey-Fuller Test Equation

Dependent Variable: D(LNGDP,2)

Method: Least Squares

Date: 07/23/14 Time: 14:24

Sample (adjusted): 1982Q2 2012Q4

Included observations: 123 after adjustments

\begin{tabular}{lrllr}
\hline \hline \multicolumn{1}{c}{ Variable } & Coefficient & Std. Error & t-Statistic & Prob. \\
\hline \hline D(LNGDP(-1)) & -0.849629 & 0.210771 & -4.031052 & 0.0001 \\
D(LNGDP(-1),2) & -0.285316 & 0.167537 & -1.702997 & 0.0912 \\
D(LNGDP(-2),2) & -0.419775 & 0.123382 & -3.402221 & 0.0009 \\
D(LNGDP(-3),2) & -0.553747 & 0.076645 & -7.224863 & 0.0000 \\
$\quad$ C & 0.057298 & 0.022344 & 2.564303 & 0.0116 \\
@ TREND(1981Q1) & -0.000168 & 0.000249 & -0.674734 & 0.5012 \\
\hline \hline R-squared & 0.756997 & Mean dependent var & -0.000297 \\
Adjusted R-squared & 0.746612 & S.D. dependent var & 0.194586 \\
S.E. of regression & 0.097950 & Akaike info criterion & -1.761166 \\
Sum squared resid & 1.122525 & Schwarz criterion & -1.623986 \\
Log likelihood & 114.3117 & Hannan-Quinn criter. & -1.705444 \\
F-statistic & 72.89519 & Durbin-Watson stat & 1.909089 \\
Prob(F-statistic) & 0.000000 & & \\
\hline \hline
\end{tabular}

Logarithm of Money Supply (LnMSS)

Null Hypothesis: D(LNMSS) has a unit root

Exogenous: Constant, Linear Trend

Lag Length: 0 (Automatic - based on SIC, maxlag=7)

\begin{tabular}{lcc}
\hline \hline & t-Statistic & Prob.* \\
\hline \hline Augmented Dickey-Fuller test statistic & -3.701245 & 0.0378 \\
\hline
\end{tabular}




$\begin{array}{ccc}\text { Test critical values: } & 1 \% \text { level } & -4.296729 \\ & 5 \% \text { level } & -3.568379 \\ & 10 \% \text { level } & -3.218382\end{array}$

*MacKinnon (1996) one-sided p-values.

Augmented Dickey-Fuller Test Equation

Dependent Variable: D(LNMSS,2)

Method: Least Squares

Date: 07/20/14 Time: 16:00

Sample (adjusted): 19832012

Included observations: 30 after adjustments

\begin{tabular}{lrlrr}
\hline \hline \multicolumn{1}{c}{ Variable } & Coefficient & Std. Error & t-Statistic & Prob. \\
\hline \hline \multicolumn{1}{c}{ D(LNMSS(-1)) } & -0.660701 & 0.178508 & -3.701245 & 0.0010 \\
$\quad$ C & 0.151109 & 0.061328 & 2.463958 & 0.0204 \\
\multicolumn{1}{c}{ @ TREND(1981) } & -0.000446 & 0.002831 & -0.157539 & 0.8760 \\
\hline \hline R-squared & 0.343241 & Mean dependent var & 0.002833 \\
Adjusted R-squared & 0.294592 & S.D. dependent var & 0.158433 \\
S.E. of regression & 0.133065 & Akaike info criterion & -1.101314 \\
Sum squared resid & 0.478072 & Schwarz criterion & -0.961195 \\
Log likelihood & 19.51971 & Hannan-Quinn criter. & -1.056489 \\
F-statistic & 7.055485 & Durbin-Watson stat & 2.114110 \\
Prob(F-statistic) & 0.003428 & & \\
\hline \hline
\end{tabular}

\section{Logarithm of Total Government Expenditure (LnTGE)}

Null Hypothesis: D(LNTGE) has a unit root

Exogenous: Constant, Linear Trend

Lag Length: 1 (Automatic - based on SIC, maxlag=7)

\begin{tabular}{lccc}
\hline \hline & & & \\
& & t-Statistic & Prob.* \\
\hline \hline \multicolumn{2}{l}{ Augmented Dickey-Fuller test statistic } & -4.353657 & 0.0090 \\
\hline Test critical values: & 1\% level & -4.309824 & \\
& 5\% level & -3.574244 & \\
& 10\% level & -3.221728 & \\
\hline \hline
\end{tabular}

*MacKinnon (1996) one-sided p-values.

Augmented Dickey-Fuller Test Equation

Dependent Variable: D(LNTGE,2)

Method: Least Squares

Date: 07/20/14 Time: 16:01

Sample (adjusted): 19842012

Included observations: 29 after adjustments 


\begin{tabular}{lrlll}
\multicolumn{1}{c}{ Variable } & Coefficient & \multicolumn{1}{c}{ Std. Error } & t-Statistic & Prob. \\
\hline \hline D(LNTGE(-1)) & -1.255040 & 0.288273 & -4.353657 & 0.0002 \\
D(LNTGE(-1),2) & -0.083210 & 0.177137 & -0.469751 & 0.6426 \\
C & 0.384372 & 0.104925 & 3.663292 & 0.0012 \\
@ TREND(1981) & -0.007243 & 0.004440 & -1.631343 & 0.1154 \\
\hline \hline R-squared & 0.727446 & Mean dependent var & 0.007072 \\
Adjusted R-squared & 0.694740 & S.D. dependent var & 0.360900 \\
S.E. of regression & 0.199398 & Akaike info criterion & -0.259581 \\
Sum squared resid & 0.993994 & Schwarz criterion & -0.070989 \\
Log likelihood & 7.763928 & Hannan-Quinn criter. & -0.200516 \\
F-statistic & 22.24170 & Durbin-Watson stat & 2.334542 \\
Prob(F-statistic) & 0.000000 & & \\
\hline \hline
\end{tabular}

\section{Appendix B1. Lag Length Selection Criteria}

Difference of Logarithm of Gross Domestic Product by Income(LnGDPI)

VAR Lag Order Selection Criteria

Endogenous variables: D(LNGDP)

Exogenous variables: $\mathrm{C}$

Date: 07/23/14 Time: 14:26

Sample: 1981Q1 2012Q4

Included observations: 119

\begin{tabular}{cccccc}
\hline \hline Lag & LogL & LR & FPE & AIC & SC \\
\hline \hline 0 & 76.04948 & NA & 0.016586 & -1.261336 & -1.237982 \\
1 & 78.21333 & 4.254961 & 0.016265 & -1.280896 & -1.234188 \\
2 & 81.55171 & 6.508435 & 0.015638 & -1.320197 & -1.250135 \\
3 & 87.39141 & 11.28681 & 0.014416 & -1.401536 & -1.308120 \\
4 & 108.6811 & 40.79034 & 0.010251 & -1.742540 & $-1.625770^{*}$ \\
5 & 109.1424 & 0.876015 & 0.010345 & -1.733485 & -1.593361 \\
6 & 109.6964 & 1.042836 & 0.010423 & -1.725989 & -1.562512 \\
7 & 110.3743 & 1.264615 & 0.010480 & -1.720576 & -1.533744 \\
8 & 114.3331 & $7.318910 *$ & $0.009973 *$ & $-1.770305 *$ & -1.560119 \\
\hline \hline
\end{tabular}

* indicates lag order selected by the criterion

LR: sequential modified LR test statistic (each test at 5\% level)

VAR Lag Order Selection Criteria

Difference of LnTGE and LnMSS

Endogenous variables: D(LNMSS) D(LNTGE)

Exogenous variables: $\mathrm{C}$

Date: 07/23/14 Time: 15:39

Sample: 1981Q1 2012Q4

Included observations: 119

\begin{tabular}{ccccccc}
\hline \hline Lag & LogL & LR & FPE & AIC & SC & HQ \\
\hline \hline 0 & 178.5379 & NA & 0.000176 & -2.967024 & -2.920316 & -2.948057 \\
1 & 181.8802 & 6.516089 & 0.000178 & -2.955970 & -2.815846 & -2.899070 \\
2 & 187.7083 & 11.16643 & 0.000173 & -2.986694 & -2.753154 & -2.891861 \\
3 & 200.5604 & 24.19221 & 0.000149 & -3.135469 & -2.808514 & -3.002703 \\
4 & 258.0380 & 106.2612 & $6.07 \mathrm{e}-05^{*}$ & $-4.034253^{*}$ & $-3.613881^{*}$ & $-3.863553^{*}$ \\
5 & 258.3944 & 0.646780 & $6.46 \mathrm{e}-05$ & -3.973015 & -3.459227 & -3.764382
\end{tabular}




\begin{tabular}{lllllll}
6 & 258.8056 & 0.732583 & $6.86 \mathrm{e}-05$ & -3.912699 & -3.305496 & -3.666133 \\
7 & 259.2854 & 0.838735 & $7.29 \mathrm{e}-05$ & -3.853537 & -3.152918 & -3.569037 \\
8 & 271.7563 & $21.37855^{*}$ & $6.33 \mathrm{e}-05$ & -3.995904 & -3.201868 & -3.673471 \\
\hline \hline
\end{tabular}

* indicates lag order selected by the criterion

LR: sequential modified LR test statistic (each test at 5\% level)

\section{Appendix C1. Unrestricted Error Correction Model}

Dependent Variable: D(LNGDP)

Method: Least Squares

Date: 07/23/14 Time: 14:29

Sample (adjusted): 1983Q2 2012Q4

Included observations: 119 after adjustments

\begin{tabular}{crccc}
\hline \hline Variable & Coefficient & Std. Error & t-Statistic & Prob. \\
\hline \hline C & 0.335750 & 0.096782 & 3.469143 & 0.0008 \\
D(LNGDP(-1)) & 0.110661 & 0.101719 & 1.087916 & 0.2793 \\
D(LNGDP(-2)) & 0.110661 & 0.101719 & 1.087916 & 0.2793 \\
D(LNGDP(-3)) & 0.110661 & 0.101719 & 1.087916 & 0.2793 \\
D(LNGDP(-4)) & 0.153334 & 0.109309 & 1.402755 & 0.1639 \\
D(LNGDP(-5)) & 0.079797 & 0.101122 & 0.789122 & 0.4320 \\
D(LNGDP(-6)) & 0.079797 & 0.101122 & 0.789122 & 0.4320 \\
D(LNGDP(-7)) & 0.079797 & 0.101122 & 0.789122 & 0.4320 \\
D(LNGDP(-8)) & 0.194066 & 0.102019 & 1.902246 & 0.0601 \\
D(LNMSS) & 0.374713 & 0.133614 & 2.804444 & 0.0061 \\
D(LNMSS(-1)) & -0.169114 & 0.120786 & -1.400116 & 0.1647 \\
D(LNMSS(-2)) & -0.169114 & 0.120786 & -1.400116 & 0.1647 \\
D(LNMSS(-3)) & -0.169114 & 0.120786 & -1.400116 & 0.1647 \\
D(LNMSS(-4)) & -0.043107 & 0.134868 & -0.319625 & 0.7499 \\
D(LNTGE) & 0.231713 & 0.085605 & 2.706760 & 0.0080 \\
D(LNTGE(-1)) & -0.090342 & 0.082841 & -1.090551 & 0.2782 \\
D(LNTGE(-2)) & -0.090342 & 0.082841 & -1.090551 & 0.2782 \\
D(LNTGE(-3)) & -0.090342 & 0.082841 & -1.090551 & 0.2782 \\
D(LNTGE(-4)) & -0.014831 & 0.092424 & -0.160471 & 0.8728 \\
LNGDP(-1) & -0.252710 & 0.071253 & -3.546637 & 0.0006 \\
LNMSS(-1) & 0.102311 & 0.044374 & 2.305657 & 0.0233 \\
LNTGE(-1) & 0.163010 & 0.058723 & 2.775903 & 0.0066 \\
\hline \hline R-squared & 0.635807 & Mean dependent var & 0.055175 \\
Adjusted R-squared & 0.556961 & S.D. dependent var & 0.128248 \\
S.E. of regression & 0.085363 & Akaike info criterion & -1.918465 \\
Sum squared resid & 0.706829 & Schwarz criterion & -1.404678 \\
Log likelihood & 136.1487 & Hannan-Quinn criter. & -1.709832 \\
F-statistic & 8.063908 & Durbin-Watson stat & 2.019536 \\
Prob(F-statistic) & 0.000000 & & & \\
\hline \hline
\end{tabular}

Appendix D1. Breusch-Godfrey Serial Correlation Lm Test

Breusch-Godfrey Serial Correlation LM Test:

\begin{tabular}{llll}
\hline \hline F-statistic & 0.243142 & Prob. F(1,96) & 0.6231 \\
Obs*R-squared & 0.300633 & Prob. Chi-Square(1) & 0.5835 \\
\hline \hline
\end{tabular}


Test Equation:

Dependent Variable: RESID

Method: Least Squares

Date: 07/23/14 Time: 14:32

Sample: 1983Q2 2012Q4

Included observations: 119

Presample missing value lagged residuals set to zero.

\begin{tabular}{crccr}
\hline \hline Variable & Coefficient & Std. Error & t-Statistic & Prob. \\
\hline \hline C & -0.073755 & 0.178363 & -0.413511 & 0.6802 \\
D(LNGDP(-1)) & 0.180134 & 0.379318 & 0.474889 & 0.6359 \\
D(LNGDP(-2)) & -0.020585 & 0.110322 & -0.186593 & 0.8524 \\
D(LNGDP(-3)) & -0.020585 & 0.110322 & -0.186593 & 0.8524 \\
D(LNGDP(-4)) & -0.023138 & 0.119349 & -0.193864 & 0.8467 \\
D(LNGDP(-5)) & -0.044840 & 0.136291 & -0.329000 & 0.7429 \\
D(LNGDP(-6)) & -0.014223 & 0.105537 & -0.134769 & 0.8931 \\
D(LNGDP(-7)) & -0.014223 & 0.105537 & -0.134769 & 0.8931 \\
D(LNGDP(-8)) & -0.014347 & 0.106472 & -0.134746 & 0.8931 \\
D(LNMSS) & 0.004545 & 0.134455 & 0.033804 & 0.9731 \\
D(LNMSS(-1)) & -0.071657 & 0.189268 & -0.378603 & 0.7058 \\
D(LNMSS(-2)) & 0.041443 & 0.147539 & 0.280893 & 0.7794 \\
D(LNMSS(-3)) & 0.041443 & 0.147539 & 0.280893 & 0.7794 \\
D(LNMSS(-4)) & 0.038155 & 0.155949 & 0.244666 & 0.8072 \\
D(LNTGE) & 0.002503 & 0.086091 & 0.029076 & 0.9769 \\
D(LNTGE(-1)) & -0.017115 & 0.090118 & -0.189919 & 0.8498 \\
D(LNTGE(-2)) & 0.022183 & 0.094554 & 0.234610 & 0.8150 \\
D(LNTGE(-3)) & 0.022183 & 0.094554 & 0.234610 & 0.8150 \\
D(LNTGE(-4)) & 0.022049 & 0.102999 & 0.214067 & 0.8309 \\
LNGDP(-1) & 0.054084 & 0.130947 & 0.413019 & 0.6805 \\
LNMSS(-1) & -0.019425 & 0.059468 & -0.326644 & 0.7446 \\
LNTGE(-1) & -0.037473 & 0.096182 & -0.389608 & 0.6977 \\
RESID(-1) & -0.244568 & 0.495985 & -0.493094 & 0.6231 \\
\hline \hline R-squared & 0.002526 & Mean dependent var & $-2.66 \mathrm{E}-15$ \\
Adjusted R-squared & -0.226061 & S.D. dependent var & 0.077396 \\
S.E. of regression & 0.085698 & Akaike info criterion & -1.904188 \\
Sum squared resid & 0.705043 & Schwarz criterion & & -1.367046 \\
Log likelihood & 136.2992 & Hannan-Quinn criter. & -1.686072 \\
F-statistic & 0.011052 & Durbin-Watson stat & 2.004649 \\
Prob(F-statistic) & 1.000000 & & & \\
\hline \hline
\end{tabular}


Appendix E1. Test For Dynamic Stability

Inverse Roots of AR/MA Polynomial(s)

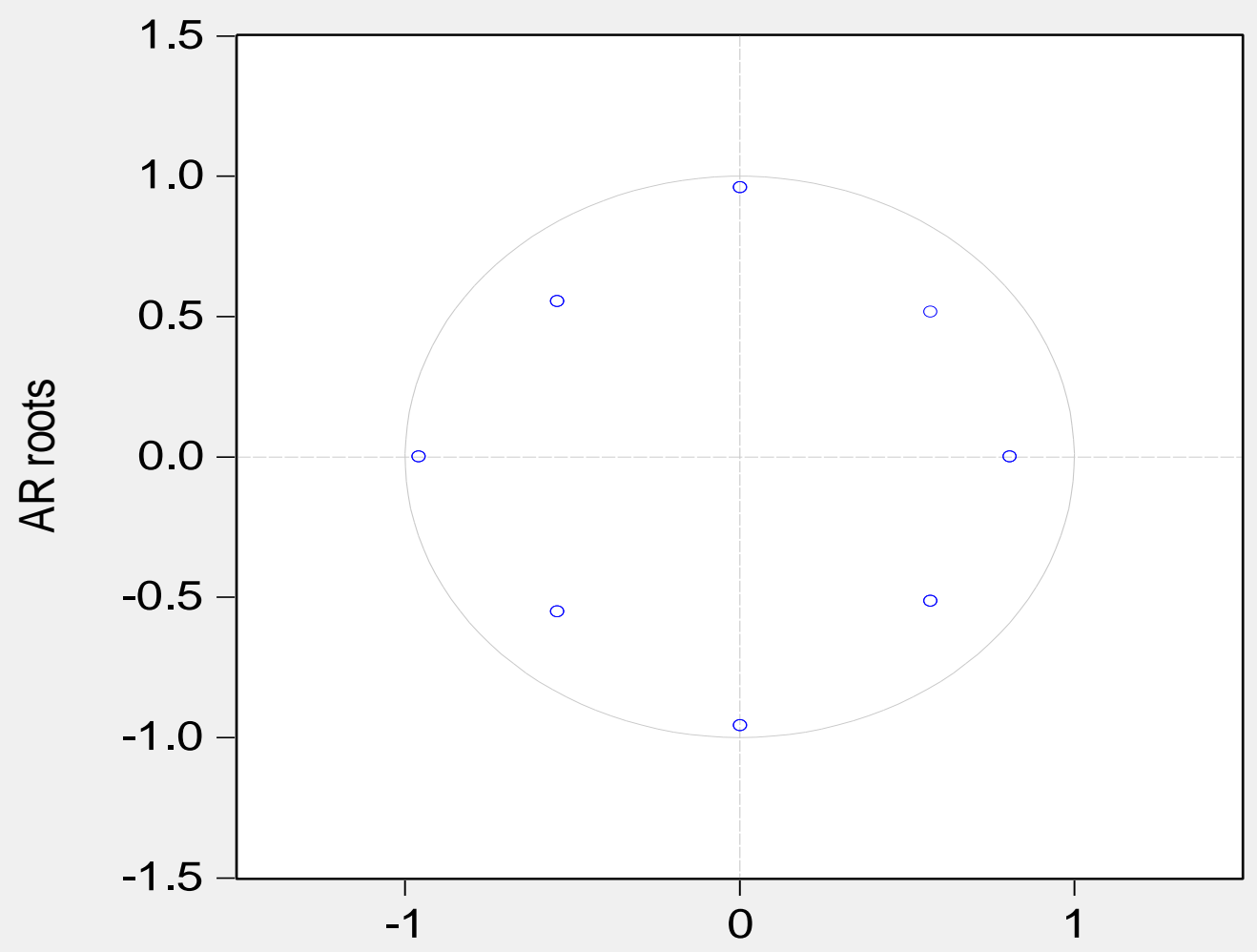

Appendix F1. Bound Test

Wald Test:

Equation: Untitled

\begin{tabular}{lccc}
\hline \hline Test Statistic & Value & df & Probability \\
\hline \hline F-statistic & 4.347412 & $(3,97)$ & 0.0064 \\
Chi-square & 13.04224 & 3 & 0.0045 \\
\hline \hline
\end{tabular}

Null Hypothesis: $C(20)=C(21)=C(22)=0$

Null Hypothesis Summary:

\begin{tabular}{lcc}
\hline \hline Normalized Restriction $(=0)$ & Value & Std. Err. \\
\hline \hline $\mathrm{C}(20)$ & -0.252710 & 0.071253 \\
$\mathrm{C}(21)$ & 0.102311 & 0.044374 \\
$\mathrm{C}(22)$ & 0.163010 & 0.058723 \\
\hline \hline
\end{tabular}

Restrictions are linear in coefficients. 


\section{Appendix G1. Restricted Error Correction Model}

Dependent Variable: D(LNGDP)

Method: Least Squares

Date: 07/23/14 Time: $14: 50$

Sample (adjusted): 1983Q3 2012Q4

Included observations: 118 after adjustments

\begin{tabular}{crcrr}
\hline \hline Variable & Coefficient & Std. Error & t-Statistic & Prob. \\
\hline \hline C & -0.003633 & 0.020825 & -0.174449 & 0.8619 \\
D(LNGDP(-1)) & 0.728280 & 0.246492 & 2.954575 & 0.0039 \\
D(LNGDP(-2)) & 0.003521 & 0.094633 & 0.037212 & 0.9704 \\
D(LNGDP(-3)) & 0.003521 & 0.094633 & 0.037212 & 0.9704 \\
D(LNGDP(-4)) & 0.044540 & 0.105116 & 0.423720 & 0.6727 \\
D(LNGDP(-5)) & -0.106150 & 0.100908 & -1.051946 & 0.2954 \\
D(LNGDP(-6)) & 0.003116 & 0.097833 & 0.031847 & 0.9747 \\
D(LNGDP(-7)) & 0.003116 & 0.097833 & 0.031847 & 0.9747 \\
D(LNGDP(-8)) & 0.117780 & 0.099018 & 1.189480 & 0.2371 \\
D(LNMSS) & 0.381650 & 0.130467 & 2.925266 & 0.0043 \\
D(LNMSS(-1)) & -0.396819 & 0.158514 & -2.503368 & 0.0140 \\
D(LNMSS(-2)) & 0.005825 & 0.115712 & 0.050341 & 0.9600 \\
D(LNMSS(-3)) & 0.005825 & 0.115712 & 0.050341 & 0.9600 \\
D(LNMSS(-4)) & 0.128225 & 0.128634 & 0.996818 & 0.3213 \\
D(LNTGE) & 0.231681 & 0.084713 & 2.734895 & 0.0074 \\
D(LNTGE(-1)) & -0.147535 & 0.088002 & -1.676508 & 0.0968 \\
D(LNTGE(-2)) & 0.001109 & 0.075409 & 0.014706 & 0.9883 \\
D(LNTGE(-3)) & 0.001109 & 0.075409 & 0.014706 & 0.9883 \\
D(LNTGE(-4)) & 0.075091 & 0.089184 & 0.841982 & 0.4018 \\
RESIDUAL(-1) & -0.880588 & 0.267070 & -3.297222 & 0.0014 \\
\hline \hline R-squared & 0.627684 & Mean dependent var & 0.055643 \\
Adjusted R-squared & 0.555500 & S.D. dependent var & 0.128693 \\
S.E. of regression & 0.085801 & Akaike info criterion & -1.920316 \\
Sum squared resid & 0.721451 & Schwarz criterion & -1.450708 \\
Log likelihood & 133.2986 & Hannan-Quinn criter. & -1.729641 \\
F-statistic & 8.695644 & Durbin-Watson stat & 2.006329 \\
Prob(F-statistic) & 0.000000 & & & \\
\hline \hline & & & & \\
\hline
\end{tabular}

\section{Copyrights}

Copyright for this article is retained by the author(s), with first publication rights granted to the journal.

This is an open-access article distributed under the terms and conditions of the Creative Commons Attribution license (http://creativecommons.org/licenses/by/4.0/). 